\title{
Business rescue: Adapt or die
}

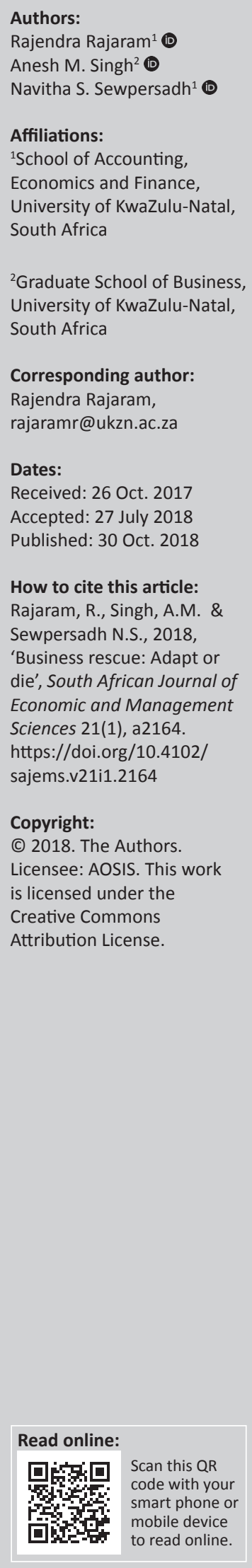

Background: The low success rate of business rescue has prompted debate relating to the effectiveness and continued suitability of business rescue as a mechanism to rehabilitate financially distressed companies. Although this legislation was implemented in May 2011, statistics indicate that the success rate for business rescues is only approximately $12 \%$. A feature of the business rescue environment in South Africa is the lack of knowledge, necessitating more research in the field.

Aim: This study focused on changes required to ensure the survival and increased success of the business rescue legislation.

Setting: This research was undertaken in South Africa between 2015 and 2017.

Methods: A mixed-methods research approach was utilised for the study. The approach entailed interviews with 7 of the top 10 business rescue practitioners to diagnose reasons for business rescue failure and establish factors that would contribute to successful business rescues. A survey was conducted with the membership of the Turnaround Management Association of Southern Africa.

Results: The survey was mailed to 130 members and the response rate was $54 \%$. This study found that the causes of business rescue failures are mainly attributable to the skills deficit of the business rescue practitioner or the practitioner's abuse of legislation. There is also a negative impact of appointing a liquidator as a business rescue practitioner. Other factors contributing to the failure of business rescues are management's delay in filing for business rescue, either due to the resistance of filing or their lack of awareness of their distressed status. This study also provided the ranking order for business rescue success factors with the accreditation of a business rescue practitioner being ranked as first.

Conclusion: The study chiefly focused on diagnosing and understanding the reasons for business rescue failure. The original contribution of this study to knowledge is the ranking of an accreditation framework for practitioners as the most important factor that would contribute to a successful business rescue. This study not only explains the low success rate of business rescue but ways to improve and succeed in rescuing ailing businesses.

\section{Introduction}

Substantial emphasis has been placed on the need for a corporate rescue culture because there is a greater probability of a successful reorganisation if a business rescue is attempted at a preinsolvency stage (Kastrinou \& Jacobs 2017). Over 35 years ago, the pioneering study conducted by Whetton (1980) highlighted the scarcity of studies in the management of organisational decline and the need for research to mitigate the impact of an emerging era of retrenchment. The study proposed a joint agenda for research, teaching and consulting to rectify the neglect (Whetton 1980). Therefore, there is a growing need for theoretical and empirical investigations into organisational decline. Notably, the threat of organisational decline has increased since Whetton's (1980) efforts to increase research. As evidenced in the continued weakness of the global economy, the persistent threat of decline remains a highly relevant global concern (Trahms, Ndofor \& Sirmon 2013:1278).

Internationally, the rescue system developed by the USA was incorporated in Chapter 11 of the Bankruptcy Code (1978) (herein referred to as 'Chapter 11'). In the UK, Kastrinou and Jacobs (2017) illustrated the corporate rescue culture, as publicised in the Enterprise Act (2002) together with the Insolvency Act (2000) (herein referred to as the 'UK system'). Adopting from these developed economies, South Africa introduced the Companies Act No. 71 (2008) in April 2009; however, it only came into effect on 01 May 2011 (Burke-le Roux \& Pretorius 2017). The business rescue provisions incorporated into Chapter 6 of the Companies Act (2008) (herein referred to as 'Chapter 6') led to a new regime of reform in South Africa, where business rescue was proposed 
as an alternative to liquidation for ailing businesses facing insolvency (Burke-le Roux \& Pretorius 2017). However, Burke-le Roux and Pretorius (2017) also noted that despite the revolutionary intentions of the Chapter 6 , revisions to the act commenced in 2016 because there were problems discovered within the provisions of the act.

Thus, it is essential for more research to be conducted in the field of business rescue legislation, because research in this field would further the goal of better understanding organisational decline and improving an organisation's response to financial distress (McKinley, Latham \& Braun 2014:88). As business rescue legislation focuses on distressed companies, this field forms an important focal area for research. This is because the enhancement of knowledge about the practical process of planning and performing a business rescue, specifically in relation to the establishment of factors of success, would provide a distressed company with the knowledgebased resources to obtain a profit and, ultimately, survive.

\section{Literature review}

Researchers have attempted to construct different models of the theory of the firm in order to explain the rationale for the continued existence of a business. The firm is frequently described as an economic institution whose objectives, decisions and activities are the result of fundamental market forces (Spulber 2009:11). The firm is also referred to as a point of coordination for transactions between its different stakeholders (Fleming, Heaney \& McCosker 2005:31). Jensen and Meckling (1976:3) likened the firm to a 'black box', which is operated in order to adhere to relevant market conditions relating to inputs and outputs, thereby maximising profits or returns to shareholders (Correia et al. 2011:13).

In the mid-1980s, there was an extension of the traditional view, relating to the utilisation of factors of production to maximise profits, towards one whereby the firm is conceptualised as a broad set of resources that are strategically utilised to enhance the performance of a firm (Priem \& Butler 2001:22). The resource-based view of the firm was introduced by Wernerfelt in 1984 to highlight the influence of proper utilisation of company resources on its competitive strategy and profitability (Priem \& Butler 2001:23). A logical extension to the resourcebased view of a firm is the knowledge-based view of the firm. This view emphasises the importance of knowledge as a resource (Curado 2006:5). Nonaka (1991, as cited in Curado 2006), highlighted the importance of knowledge when concluding that the only true and lasting competitive advantage in a firm is the knowledge developed by that firm. Accordingly, knowledge-based resources should become the focus of research in order that a sustainable competitive advantage is developed in the modern globally competitive economy, where knowledge is considered critical (Curado 2006:5).

The development of knowledge relating to the initial failure and subsequent rescue of a firm would serve as an enabler for a distressed firm to return to profitability and sustainability. When companies are established, an inherent expectation is that they will survive in the long run. However, many businesses experience financial distress because of mismanagement and adverse economic forces. Operating under decline implies operating under distress, at which point, if the business is not rehabilitated, its death and closure would result (Baird 2014:17). A rebirth can be achieved by the development of knowledge resources and capabilities relating to the field of business rescue. Baird (2014:3) concluded that the identification or acquisition of knowledge, best practices or secrets of success, contributes to the rebirth of dying or distressed organisations. The acquisition or enhancement of a firm's knowledge resources in relation to the planning and performance of a business rescue process will contribute to improved profitability and thereby facilitate a resurrection and continued existence of the firm.

Business rescue was introduced to rehabilitate financially distressed companies and thereby prevent their liquidation (Lotheringen 2013). The Companies and Intellectual Property Commission (CIPC) estimated that the success rate of business rescues is approximately $12 \%$ to $14 \%$ (Lotheringen 2013). More recent statistics released by the CIPC indicate that the success rate has not improved since 2013 (Voller 2015). Existing literature identifies certain factors, which translate into a successful business rescue. These factors include the effective planning of a business rescue (Institute of Directors in Southern Africa 2009), the management of the business rescue process (Levenstein 2011), access to funding during business rescue (Du Preez 2012) and effective communication with stakeholders (Van der Burgh 2013).

\section{Legislative framework}

Many international solvency systems have established a formal process to rehabilitate companies experiencing financial distress (Pretorius \& Rosslyn-Smith 2014:109). Conradie and Lamprecht (2015) found that the international business rescue regimes and Chapter 6 share similar goals. Thus, the USA and the UK rescue mechanisms were selected for review for the following reasons:

- The business rescue mechanism of these countries represents the latest developments internationally.

- There are similarities in law between South Africa and the UK.

- The US regime is credited with initiating the modern changes associated with business rescue (Du Preez 2012:10).

\section{United States rescue mechanism}

Chapter 11 governs reorganisation that serves to resurrect ailing businesses, which is an alternative to Chapter 7, where there is an immediate liquidation of a business. This is achieved primarily by encouraging financial restructuring that is binding on all parties (Bracewell \& Giuliani 2012:1). Its commencement may be voluntary, where it is filed by the debtor or company, or involuntarily, where it is filed by the creditors. When a creditor involuntarily files a petition, it involves an amount of risk as the court may order the 
petitioners to pay compensatory and/or punitive damages if it finds that the petition was filed in bad faith (Mindlin 2013:2). However, Chapter 11 also allows a company experiencing financial difficulty substantial protection against its creditors. This protection is in the form of a moratorium on payments, which is effective until a plan of reorganisation is adopted by the company (Bharath, Panchaegesan \& Werner 2013:1).

The 'debtor in possession' under Chapter 11 refers to management of the distressed firm, who work together with the business rescue practitioner to produce a plan for the bankruptcy court to ratify (Burke-le Roux \& Pretorius 2017). A key focus of Chapter 11 is the preservation of the going concern value over the liquidation value by means of a plan of reorganisation (Jones Day 2007:6). This mechanism allows management to maintain control over and continue to operate the business. Therefore, Chapter 11 provides managers of a distressed firm with an unparalleled ability to control the reshaping of the firm's capital structure (Baird 2014:1).

\section{United Kingdom rescue mechanism}

The UK formal mechanism to rescue a financially distressed company is referred to as 'administration', which is legislated according to the Enterprise Act of 2002. According to Pretorius and Rosslyn-Smith (2014:116), this act is considered the best contender to rank with Chapter 11. The Enterprise Act aims to achieve a successful resurrection of a financially distressed company by the creation of breathing space, during which a company is given time to formulate a plan for reorganisation (Jones Day 2007:8). The primary goal of administration is to rescue a financially distressed company as a going concern (Museta 2011:57). If this primary goal is not achievable, then administration seeks a better result for the creditors or the distribution to secured or preferential creditors in the event of a liquidation.

Loubser (2010:56) noted that administration is only possible when approved by the courts and that such approval relies heavily on the information supplied by the prospective administrator. The notification process does not require the general body of creditors to be informed and is limited to the company, the applicant and the prospective administrator, who must be appointed before the application. The strictly regulated system of appointment of the administrator is an important feature of the success of the process (Loubser 2010:197; Museta 2011:59). An administrator who is not a member of a professional body or authorised by the Secretary of State is strictly prohibited (Loubser 2010:198). Acting as an administrator without the required qualification is an offence, which may be sanctioned by imprisonment or a fine (Museta 2011:59).

Management of a company in administration is required to carry out their statutory duties during the administration period (Museta 2011:61). Within 8 weeks of the administrator's appointment, a proposal for achieving a rescue of the business is presented and such a proposal requires a simple majority vote of those creditors present. An administration expires after 12 months unless the court approves an extension (Jones Day 2007:15). A key difference to the USA's Chapter 11 is that the UK system involves the appointment of an administrator to oversee the process and therefore utilises a 'practitioner in possession' principle, as opposed to the USA's debtor in possession (Pretorius \& Rosslyn-Smith 2014:116).

\section{South Africa's rescue mechanism}

The former regime of rescuing financially distressed businesses was handled under judicial management as provided for under the section 'Compromises and Arrangements' in the Companies Act 61, 1973. However, this was overhauled by Chapter 6, 'Business Rescue and Compromise with Creditors', as provided for under the Companies Act of 2008, which defines 'business rescue' as measures to facilitate the rehabilitation of a financially distressed company through the temporary supervision of the affairs, business and property of the company. The supervision of affairs is carried out by a business rescue practitioner, who is appointed either by the directors in voluntary filings or by court appointments as per Section 131. Therefore, financially distressed businesses can prevent liquidation or forced closure by enacting an informal turnaround or a legislated business rescue. One of the main objectives of Section 7 of the Companies Act (2008) is to provide for the efficient rescue and recovery of financially distressed companies, in a manner that balances all relevant stakeholders' rights and interests.

Thus, the Companies Act of 2008 provides for two preinsolvency proceedings, namely Section (s.) 129, 'Business Rescue', and s. 155, 'Compromise with Creditors'. Although both pre-insolvency proceedings provide an ailing debtor trying to evade liquidation with access to corporate reorganisation, its procedures are drawn from the international rescue mechanisms discussed in the sections above. The s. 129 business rescue provisions are considered more traditionally like the administration procedure under the UK system (Bradstreet 2014), because under business rescue, the company's management loses decision-making abilities and is displaced by the business rescue practitioner (Bradstreet 2014). In contrast, the provisions in Section 155 for compromise with creditors, although simpler, are similar to those of the USA's Chapter 11 debtor in possession, where the debtor maintains control of its affairs and a compromise is reached between the company and the majority of its creditors (Bradstreet 2014).

Therefore, the 'debtor-friendly' system under the Companies Act (2008) that allows the debtor company's participation in the rescue sharply diverges from the traditional creditororiented approach under the previous Companies Act 61 (1973) (Bradstreet 2014). However, the study by Pretorius (2016) found a debtor-friendly fallacy after an examination of the legislative tension and its practical outcome posited a de facto creditor-friendly regime. Calitz and Freebody (2016) posit that a sudden 180-degree change to a debtor-friendly 
system after having a creditor-friendly regime in South Africa for so long may not yield positive effects in the short term. Notably, irrespective of who initiates the business rescue, the process would only continue if more than $75 \%$ of the creditors accept the business rescue plan (Kastrinou \& Jacobs 2017). Therefore, dissenting minority creditors are bound by the majority of the creditors who approve the business rescue plan in rescue proceedings (Kastrinou \& Jacobs 2017).

Another feature of the Companies Act (2008) is Section 135, which allows post-commencement financing to ailing companies that have filed for business rescue. Postcommencement financing is funding available to companies after filing for administration or reorganisation, and it is used to enable the companies to pay for rehabilitation fees, carry on trade and pay for fixed costs (Mkhondo \& Pretorius 2017). According to Mkhondo and Pretorius (2017), many regimes use post-commencement financing in some form, which is typically legislated or otherwise regulated. This type of financing is akin to the USA's debtor in possession financing (Mkhondo \& Pretorius 2017). Section 134 of the Companies Act (2008) deals with protection of property interests, apart from sale of assets as part of the business rescue plan; the business under rescue can dispose of assets in the ordinary course of business, at arm's length and for a value approved by the business rescue practitioner. According to Mkhondo and Pretorius (2017), the Companies Act (2008) does not cater for prepackaged sales, which encompasses new or existing funders acquiring a (further) equity in the company or the formation of a new company to acquire the assets of the company.

\section{Success factors of the US rescue mechanism \\ Business rescue process}

The study by Warren and Westbrook (2009:629) concluded that a key success factor of a Chapter 11 rescue is the speed at which cases are resolved. Their study highlighted that a typical Chapter 11 turnaround was resolved in about 9 months and that the average time for the resolution of a case was about 11 months. In contrast, the study by Conradie and Lamprecht (2015) identified key indicators for evaluating success, namely the going concern status on exiting business rescue and the comparison of the creditors' actual return as opposed to the liquidation return. Furthermore, the findings showed a need to establish indicators that would measure the short- to long-term economic viability of the business after reorganisation. Additionally, the study by Conradie and Lamprecht (2018) illustrated that experts in the sample reached a high level of consensus on several indicators of a successful business rescue - notably, the need to compare the actual number of jobs saved as opposed to the numbers estimated in the business rescue plan. This study also found that $64 \%$ of the experts agreed that a success indicator based on the public interest (PI) score should be used but recommend that a customised PI scorecard or verifier be researched and developed.

\section{Business rescue practitioner}

The study by Loubser (2010:246) noted similarities between the Chapter 6 rescue legislation and the UK system of administration, such as the appointment of a practitioner or administrator. Loubser (2010) recommended the use of changes in the South African legislation to address current shortfalls to the appointment of a business rescue practitioner, in particular the absence of a system of accreditation for business rescue practitioners. Likewise, Pretorius' (2015) study also found a need to address issues such as the accreditation, regulation and competencies of the practitioner. Furthermore, Pretorius (2015) highlighted the dominant role of the business rescue practitioner, referred to as a 'disproportionate influencer', which refers to the power and influence exercised in a business rescue. Burke-le Roux and Pretorius (2017) also examined the role of business rescue practitioners as disproportionate influencers. However, this study focused on entrepreneurial learning during a formal business rescue by examining three key content dimensions, namely, rescue process, business-related and personal learnings. Interestingly, entrepreneurs within the sample that had positive experiences of business rescue were able to gain more knowledge in all the criteria tested in comparison with entrepreneurs with negative experiences. Therefore, this study's key finding was that the behaviour of the business rescue practitioner was a significant driving or restraining factor on entrepreneurial learning.

\section{Courts}

Mindlin (2013:18) stated that bankruptcy judges are experienced specialists who possess sound commercial judgement as they have handled thousands of cases and have practised as bankruptcy lawyers for many years. However, the study by Joubert (2013) found that there was uncertainty experienced by the courts regarding the meaning of 'reasonable prospect' when permitting an order of business rescue to be examined through case law. Joubert (2013) established that Eloff A.J. in the Southern Palace case applied the criteria of restoring the company to 'a successful one', which set a precedent that subsequent judges used. This criterion of 'a successful one' set a high threshold akin to the burden of proof that was required in terms of judicial management (Joubert 2013). Although there has not been a development of a clear definition of the recovery requirement as yet, the high threshold has been lowered and a more constructive approach applied, as seen in the ensuing Propspec case decision (Joubert 2013).

\section{Prepackaged funding}

Bracewell and Giuliani (2012:24) highlighted the use of prepackaged plans as a success indicator. This involves an arrangement whereby the debtor's plan, on the first day of court proceedings, is accompanied by votes confirming the plan. This arrangement is achieved as the debtor coordinates with major creditor groups prior to filing for Chapter 11 and a plan is agreed to in advance. This concurs with Mindlin's 
(2013:18) study, which highlighted the active role of creditors, especially large creditors, and noted that an official committee of creditors is appointed in most sizeable Chapter 11 cases. Pretorius (2015) found that over 50\% of the respondents in the study supported a bigger role for the creditors in the appointment of a business rescue practitioner.

Mindlin (2013) also found that the availability of Chapter 11 funding results in companies having a better chance of meeting their liquidity needs after filing. Many investors are eager to acquire companies that have entered Chapter 11. In addition, there is good access to information. Bharath et al. (2013:10) also emphasised the increase in the availability of funding for a Chapter 11 reorganisation as a success factor. Pretorius (2015) found that in $29 \%$ of the cases, business rescue practitioners were able to obtain post-commencement funding, which is thus a limitation to business rescue success. Likewise, the study by Calitz and Freebody (2016) established the significance of post-commencement finance as an important business rescue success indicator. The lack of post-commencement finance in South Africa can be attributed to the underdevelopment of the legislation (Calitz \& Freebody 2016).

In contrast, Mkhondo and Pretorius (2017) established that prepackaged funding is used widely in many regimes and revealed that many of the funding institutions employ a variety of complementary funding mechanisms (prepackaging interchangeably with other post-filing mechanisms). Funding institutions, particularly hedge funds, frequently apply prepackaged funding as an entry to the acquisition of such distressed assets (Mkhondo \& Pretorius 2017). Because the acquisition of the distressed assets is usually before the default event, these hedge funds have qualified investment professionals to perform actuarial calculations in order to ensure optimal values for the instruments (Mkhondo \& Pretorius 2017). Furthermore, Mkhondo and Pretorius (2017) found that sophisticated funding mechanisms and a vibrant distress funding market are correlated, which forms the foundation of prepacks.

\section{Other factors}

Bharath et al. (2013:10) also highlighted the emergence of key employee retention plans, which enable key, high-earning employees to receive court-approved bonuses to induce them to remain with the firm during the reorganisation. Many creditors have concluded that providing these incentives to management was preferable to the time-consuming and disruptive process of recruiting new managers. Other factors cited include management's exclusive right to propose a reorganisation plan within 120 days.

In summary, the US Chapter 11 and the UK administration procedure highlighted certain factors of success in the evaluation of turnarounds. However, an emerging economy like South Africa cannot rely blindly on the success indicators used by foreign researchers. The literature review has shown that there is an absence of research on the identification and ranking of a common set of factors relating to businesses either in business rescue or intending to file for business rescue. This study aims to contribute to the extant literature by using business rescue experts to identify and rank a collective set of indicators that can contribute towards a successful business rescue.

\section{Research methodology Research objectives and questions}

The objective of this study was to gauge the consensus on what highly knowledgeable and experienced business rescue practitioners would consider as indicators of a successful business rescue in South Africa. Therefore, the following research questions were formulated in order to achieve the research objective:

- What are the indicators of a successful business rescue according to turnaround managers?

- Which indicators, ranked from lowest to highest, contribute to successful business rescues according to the CIPC top 10 practitioners?

\section{Research design}

Saunders, Lewis and Thornhill (2003:96) recommended qualitative research to find out 'what is happening, to seek new insights, to ask questions and to assess phenomena in a new light'. The three principal methods that they advocated to achieve this objective are to undertake a search of literature, talk to experts, and conduct interviews (Saunders et al. 2003:97). Therefore, a mixed-methods approach was utilised for this study.

\section{Sampling}

The Companies Act (2008) states that a practitioner should be a member of the law, accounting or business management profession (Government Gazette 2009). In addition, the Companies Act (2008) also states that the practitioner should have experience in the practice of business turnaround (Government Gazette 2009). Therefore, because the intention of this study was to obtain insight from expert practitioners, accordingly the practitioners selected for the interview were required to be experienced and possess substantial knowledge of the business rescue process. This requirement is aligned to the Companies Act (2008), which places emphasis on the experience of the business rescue practitioner.

Turnaround Management Association (TMA) is an organisation that regulates and sets standards for the rehabilitation of financially distressed companies (Baird 2014:42). In an effort to obtain expert opinion about the business rescue process, 130 registered members of TMA's local affiliate, Turnaround Management Association Southern Africa (TMA-SA), were requested to respond to the questionnaire. TMA-SA represents the Southern African region (South Africa, Swaziland, Lesotho, Namibia, Angola, Zimbabwe and Mozambique). 
Furthermore, a list of the top 10 practitioners that was released by the CIPC in March 2015 was used as a sample for the expert interviews conducted. The top seven practitioners are ranked according to the number of business rescue practitioner appointments (Voller 2015). Because of their substantial exposure to business rescues, these practitioners have significantly more practical experience of the business rescue process and can provide valuable insights. All interviewees who participated in the study had served as a business rescue practitioner for more than 3 years and had been appointed to more than five business rescues. The average number of business rescue practitioner appointments per interviewee was approximately 51 . This is above the average of seven business rescue practitioner appointments per conditionally registered business rescue practitioner (Voller 2015).

\section{Data collection}

Sekaran and Bougie (2013:112) stated that the manner in which data is collected for solving a research problem has a fundamental impact on the effectiveness of solving the problem. The deductive method of solving a research problem emphasises the need to collect data so that any causal relationship that exists between variables can be identified and explained (Saunders et al. 2003:88). To effectively address the aim of this research, it was vital for the data collection method to facilitate the establishment and ranking of factors that result in a successful business rescue. An efficient data collection method recommended by Sekaran and Bougie (2013:147) is to use a questionnaire so that respondents can record their answers.

\section{Questionnaire design}

Although the questionnaire is a formidable tool to gather data, it is critical that the questionnaire be answered by individuals who will provide the correct answers to solve the research problem (Sekaran \& Bougie 2013:240). For that reason, the questionnaire, comprising closed-ended questions, was used to address the objective of this study and aligned to the research objective. The questions were aligned to the research aim. The interview questions facilitated an understanding of business rescue failure and the interventions required to ensure the survival of the organisation.

\section{Discussion of research findings}

Although the introduction of business rescue legislation resulted in a significant difference in the manner that financially distressed companies were managed, there were 'no guidelines, structure or case law'. This led to difficulties being experienced during the implementation of the legislation as a result of its complex nature. However, since implementation, there have been more guidelines and assistance to understand the scope and nature of business rescue legislation, because it was misunderstood upon implementation. All seven business rescue practitioners supported the implementation of the business rescue legislation because of the potential to grow the economy. However, all interviewees indicated that there was a level of unpreparedness when the legislation was implemented in 2011. In Figure 1, interviewees mentioned reasons for the unpreparedness; notably, four interviewees stated that the main reason was complexity of legislation.

The low success rate of business rescue was acknowledged and accepted by all interviewees. The reasons provided for the low success rate are presented in Table 1.

According to Table 1, three interviewees felt that the low success rate was attributable to companies filing for business rescue late, mainly as a result of management ignoring initial distress signals and/or not being aware of the business rescue legislation and the remedy offered to rehabilitate a financially distressed company. These practitioners encountered numerous failed business rescues that would have been successful if the rescue had commenced earlier. By the time practitioners got involved, it was too late for the rescue to be a success. According to the interviewees, creditors were reluctant to support the business rescue at an advanced stage of distress, which resulted in a failed rescue. An interviewee linked the late commencement of business rescue with management not complying with Section 129(7) of the Companies Act. According to this section, if the board of a company has reasonable grounds to believe that the company is financially distressed, but the board has not adopted a resolution to commence business rescue, the board must deliver a written notice to each affected person setting out the reasons for not filing for business rescue. The interviewee suggested that management of companies that

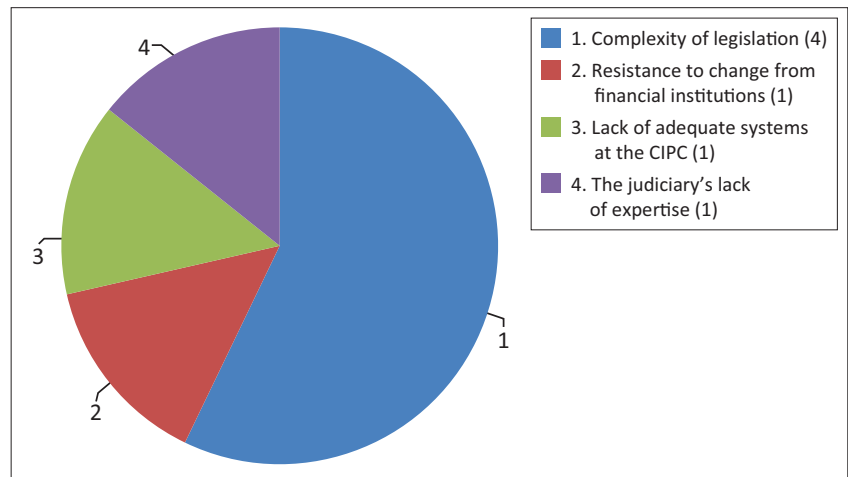

Source: Rajaram, R., 2016, 'Success factors for business rescue in South Africa', Unpublished doctoral dissertation, University of KwaZulu-Natal, Pietermaritzburg

FIGURE 1: Reasons provided for the unpreparedness in the application of the legislation.

TABLE 1: Reason for low success rate in a business rescue.

\begin{tabular}{|c|c|c|c|c|c|c|c|}
\hline Reason for low success rate & BR1 & BR2 & BR3 & BR4 & BR5 & BR6 & BR7 \\
\hline Late filing for business rescue & - & $\checkmark$ & - & $\checkmark$ & $\checkmark$ & - & - \\
\hline $\begin{array}{l}\text { Extensive litigation and absence of } \\
\text { specialised courts }\end{array}$ & - & $\checkmark$ & - & - & $\checkmark$ & - & $\checkmark$ \\
\hline Lack of post-rescue finance & - & $\checkmark$ & - & - & $\checkmark$ & - & - \\
\hline $\begin{array}{l}\text { Unaccredited business rescue } \\
\text { practitioners }\end{array}$ & $\checkmark$ & - & - & - & - & $\checkmark$ & - \\
\hline Abuse of business rescue & - & - & $\checkmark$ & - & - & - & - \\
\hline
\end{tabular}

Source: Rajaram, R., 2016, 'Success factors for business rescue in South Africa', Unpublished doctoral dissertation, University of KwaZulu-Natal, Pietermaritzburg $\mathrm{BR}$, business rescue. 
are financially distressed has a simple choice - they must either file for business rescue or comply with s. 129(7) of the Companies Act. According to him, non-compliance with Section 129(7) delays the commencement of the business rescue by about 'eight to twelve months'. As a testament to the low compliance rate, the interviewee mentioned that he had not seen a Section 129(7) notice in the sector since implementation of the business rescue legislation.

An interviewee indicated that there is a negative correlation between the time that elapses and the asset value in a distressed company. An unfortunate consequence of the diminution in asset value is that it becomes very difficult or impossible to secure post-rescue finance. According to this interviewee, he did not find it difficult to get post-rescue finance in the normal course of events. However, when a business rescue commences late, it is difficult to obtain finance.

Furthermore, two interviewees highlighted the negative impact of extensive litigation on a business rescue. Another interviewee mentioned that he had been involved in business rescues where the business rescue plan had been voted on and approved but then there was litigation that prevented the successful implementation of the plan. Some of the litigation had been ongoing for more than 3 years, which prevented a successful implementation of the business rescue plan and the completion of the rescue. The impact of the extensive litigation is compounded because of the inability of courts to urgently resolve business rescue cases. An interviewee with many years of litigation experience in business rescue stated a belief that the lack of judicial infrastructure and skills have the impact of muting the benefits of business rescue legislation.

One of the interviewees mentioned that, in his opinion, the single most important reason for the low success rate was management abuse of the provisions of Chapter 6 legislation. The abuse manifests itself frequently when management, requiring more time before a liquidation, file for a business rescue. In these instances, there is no realistic chance of a successful business rescue. Filing for business rescue under such circumstances is simply a mechanism to delay a liquidation and to plan around the needs of management.

Another factor that surfaced, in relation to failed business rescues, was the adverse impact of unaccredited business rescue practitioners. According to two interviewees, the lack of experience and the necessary skills among practitioners to deal with difficult circumstances generally had an adverse impact on the success rate of business rescues. All seven interviewees felt that business rescue practitioners contribute significantly towards a failed business rescue. The unanimous response from the interviewees prompted the researcher to probe why business rescue practitioners are often the cause of failed business rescues. The reasons provided are illustrated in Figure 2.

According to Figure 2, business rescue practitioners cause rescues to fail because of insufficient skills and knowledge. A majority of the interviewees highlighted the lack of

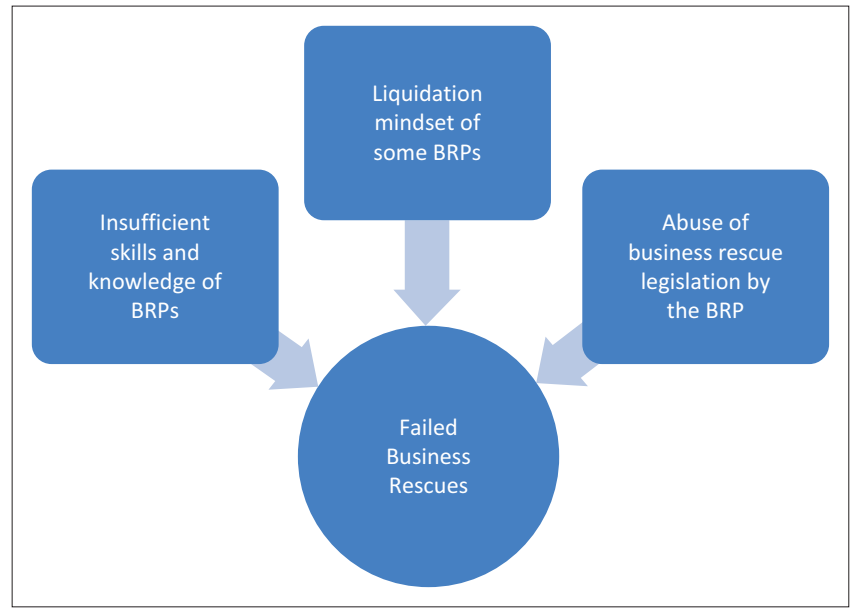

Source: Rajaram, R., 2016, 'Success factors for business rescue in South Africa', Unpublished doctoral dissertation, University of KwaZulu-Natal, Pietermaritzburg

FIGURE 2: Business rescue practitioners' role in failed business rescues.

knowledge and understanding of business rescue legislation as justification for their belief that business rescue practitioners are often the cause of failed rescues. Additionally, some of the interviewees reported that business rescue practitioners lacked managerial skills to manage finances and deadlines. Although practitioners cannot be expected to be a legal, financial and managerial expert, they should possess managerial skills to delegate or outsource tasks that they are incapable of performing themselves. An interviewee shared his experience of two instances where procedural mistakes were made by the business rescue practitioner that had a negative outcome on the rescues. According to this interviewee, many business rescues were terminated because of practitioners failing to follow legislative procedures, especially in the first 7 days after filing for business rescue. This demonstrates that if practitioners do not understand, and consequently do not comply with, the procedural requirements of legislation, then the rescue becomes a nullity (which is classified as a failed business rescue). One of the interviewees also expressed concern about the communication skills of business rescue practitioners. He indicated that business rescues were failing because of the practitioners' inability to communicate effectively and transparently with creditors, including financial institutions. For example, it was mentioned that practitioners often failed to provide the worst-case scenario to the creditors, which caused creditors to be over-optimistic. Consequently, creditors refused to negotiate or compromise during a business rescue, resulting in a failed rescue.

The active role of liquidators in the business rescue sector was highlighted by an interviewee because many liquidators are appointed as business rescue practitioners. He considered this to be a paradox, as liquidators are skilled at salvaging and selling business components rather than rehabilitating a distressed business. In his view, many liquidators attempt to rescue a business without the financial, business modelling and turnaround skills. Many liquidators do not possess the basic understanding of financial statements and do not understand financial terminology. A liquidator's training 
and focus is to maximise the salvage value of a distressed business. It becomes problematic when these skills are applied to rehabilitate a business. The practitioner's observation was that the appointment of liquidators as business rescue practitioners was causing business rescues to fail, because the liquidators lacked the skills required to successfully rehabilitate a financially distressed company.

The adverse role of practitioners in the abuse of the business rescue process was highlighted by an interviewee. He expressed concern that some practitioners acted on behalf of unscrupulous business owners to abuse business rescue legislation. In those cases, as mentioned above, owners filed for business rescue with the intent of using the process to some other ends (such as delaying a liquidation). The practitioner was thus complicit in the process of abuse as they were aware of the business owner's intent. The failure of these business rescues is partially attributable to the practitioner as a result of their use of the legislation for purposes other than the rehabilitation of a distressed company.

As stated by Rajaram and Singh (2018), a successful business rescue practitioner should have a multitude of skills and qualifications, as seen in Figure 3.

Furthermore, the improvement requires an increased effort and changed mindset from the different role players in the sector. The factors that may contribute to an increased success are illustrated in Table 2.

According to Table 2, five interviewees were of the opinion that the accreditation of business rescue practitioners would enhance their competency and professionalism, leading to more successful business rescues. One of the interviewees

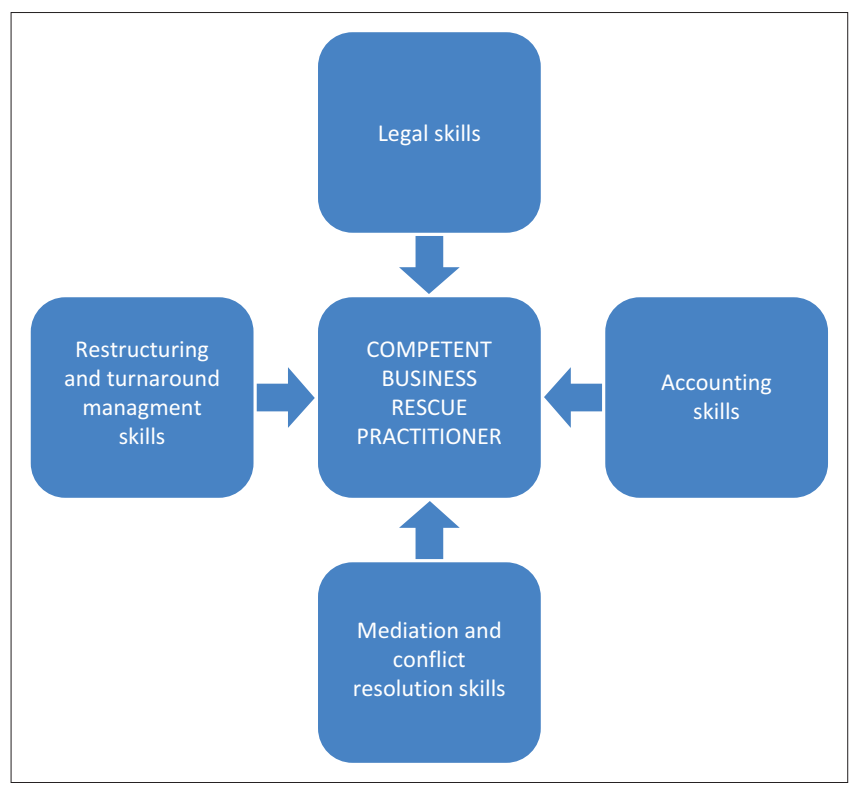

Source: Rajaram, R. \& Singh, A.M., 2018, 'Competencies for the effective management of legislated business rehabilitations', South African Journal of Economic and Management Sciences 21(1), 1-9. https://doi.org/10.4102/sajems.v21i1.1978

FIGURE 3: Competencies required to be an effective business rescue practitioner. felt that if business rescue practitioners do not conform to an accreditation framework, business rescue will not survive because of the low success rate. The demise of business rescue can be prevented by ensuring that there are more experienced and competent practitioners, which would be facilitated by an accreditation framework.

Another success factor that was highlighted by the interviewees was the increased availability of post-rescue funding. Whilst a fresh injection of long-term capital is vital for the success of a business rescue, one of the interviewees also emphasised the benefit of securing immediate, short-term funding. Such funding facilitates the continuance of the business immediately at the commencement of business rescue. The interviewee recalled that short-term payment of taxes and expenditure were major issues in several of his business rescues. If the practitioner can obtain short-term and long-term funding for the business, the rescue will be successful.

Furthermore, the business rescue success rate can be improved by educating business people so that they are more aware of business rescue as a mechanism to rehabilitate underperforming businesses. The increased awareness can be achieved by informing the public and others in the business sector about the benefits of business rescue so that the stigma attached to a business rescue is removed. Business rescue must not be seen as a death sentence. An awareness and culture of support for business rescue would definitely improve the success rate of these rescues.

A practitioner stated that an increased awareness and support for business rescue would enable an early application and commencement of business rescue. In addition, this early commencement would be facilitated by ensuring that the requirements of s. 129(7) of the act become compulsory. It is vital for the business community to take Section 129(7) seriously. The practitioner also suggested that creditors approach the court to obtain compensation from directors who do not comply with s. 129(7) of the act. If South African Revenue Services, creditors and other affected parties required strict compliance with Section 129(7), there would be earlier applications for business rescue and a higher success rate.

The success of business rescue also lies in more court cases being resolved at the Constitutional Court. According to an

TABLE 2: Factors that may result in an increased business rescue success

\begin{tabular}{|c|c|c|c|c|c|c|c|}
\hline Success factor & BR1 & BR2 & BR3 & BR4 & BR5 & BR6 & BR7 \\
\hline $\begin{array}{l}\text { Accreditation of business } \\
\text { rescue practitioners }\end{array}$ & $\checkmark$ & - & $\checkmark$ & $\checkmark$ & - & $\checkmark$ & $\checkmark$ \\
\hline Increased post-rescue funding & - & $\checkmark$ & - & - & - & $\checkmark$ & $\checkmark$ \\
\hline $\begin{array}{l}\text { Earlier filing for business } \\
\text { rescue }\end{array}$ & - & $\checkmark$ & - & $\checkmark$ & - & - & - \\
\hline Establishing specialised courts & - & - & - & - & $\checkmark$ & - & $\checkmark$ \\
\hline $\begin{array}{l}\text { Increased education and } \\
\text { awareness of business rescue }\end{array}$ & - & $\checkmark$ & $\checkmark$ & - & - & - & - \\
\hline Flexibility from labour & $\checkmark$ & - & - & - & - & - & - \\
\hline
\end{tabular}

Source: Rajaram, R., 2016, 'Success factors for business rescue in South Africa', Unpublished doctoral dissertation, University of KwaZulu-Natal, Pietermaritzburg $\mathrm{BR}$, business rescue. 
interviewee, several decisions by the Supreme Court of Appeal have been very questionable. The judges are not qualified or competent in business rescue legislation. It is important that the questionable Supreme Court of Appeal decisions be challenged at the Constitutional Court. In addition, consideration must be given to the establishment of specialised business rescue courts.

There should be a greater scrutiny of management wanting to file for business rescue, and one of the interviewees suggested that management of companies filing for business rescue should be interviewed. He said that he undertook interviews with company management whenever he was approached to be the business rescue practitioner. This interview process enabled him to assess if the business rescue was worthwhile or if the company should be liquidated.

Another interviewee mentioned that there is currently an unnatural wish by role players to save jobs. The legislation is very strict regarding labour relations and this affects the viability of a business rescue. Businesses are liquidated because of staff demands and the cost of labour. There is great pressure on the financial institutions and government organisations (such as South African Revenue Services) to vote to save jobs. However, saving jobs is costly and makes it unavoidable for the company to be liquidated. Flexibility from organised labour to allow certain retrenchments would contribute to a higher success rate.

\section{Ethical consideration}

The questionnaire for members of the Turnaround Management Association of Southern Africa and the interview schedule for business rescue practitioners were approved by the Humanities and Social Science Research Ethics Committee of the University of KwaZulu-Natal.

\section{Discussion of quantitative results Reliability}

Coakes and Steed (2010:140) stated that there are a number of different reliability coefficients. One of the most commonly used is Cronbach's alpha, which is based on the average correlation of items within a test if the items are standardised. If the items are not standardised, it is based on the average covariance among the items. Cronbach's alpha can range from 0 to 1 . The Cronbach's alpha for the questions was 0.84 . The alpha value is indicative of high internal consistency. The results of the study therefore display a high degree of reliability and integrity.

\section{Discussion of results}

Respondents were requested to complete a Likert scale question for each possible success factor. The scale comprised five categories, namely: 'strongly disagree', 'disagree', 'neutral', 'agree' and 'strongly agree'. The responses for the 'strongly disagree' and 'disagree' categories and the responses for the 'strongly agree' and 'agree' categories were combined into two categories, respectively, as listed in Table 3.

According to Table 3, 92\% of respondents either agreed or strongly agreed that strict accreditation criteria for the appointment of a business rescue practitioner would contribute to a successful rescue. In order for business rescue legislation to survive, practitioners need to become more professional and better organised. In England, an important success feature of the formal rescue process rests with the strict accreditation of administrators (Loubser 2010; Museta 2011). In South Africa, there are many professions, such as in law, auditing and accounting, that have strict accreditation criteria. The respondents to the questionnaire favour a similar route of accreditation as the main factor that would contribute to a successful business rescue.

The results in Table 3 also indicate that businesses need to use early warning signals to anticipate financial distress in order for an early commencement of business rescue, which contributes to its success. This view was supported by $79 \%$ of respondents as a success factor, which concurs with the study by Muller (2014), where the benefits of an early commencement of business rescue was illustrated in the successful rescue of Shelly Point Hotel. The early commencement of that rescue facilitated timeous raising of post-rescue finance (ranked as

TABLE 3: Business rescue success factors and ranking.

\begin{tabular}{|c|c|c|c|c|c|c|}
\hline Factor & $\begin{array}{l}\text { Disagree and } \\
\text { strongly disagree }\end{array}$ & Neutral & $\begin{array}{c}\text { Agree and strongly } \\
\text { agree }\end{array}$ & SD & Mean & Rank \\
\hline Strict accreditation criteria are needed. & 1 & 7 & 92 & 0.693 & 4.45 & 1 \\
\hline Effective communication by business rescue practitioner. & 1 & 16 & 83 & 0.749 & 4.2 & 2 \\
\hline Use of an effective business rescue plan. & 1 & 16 & 84 & 0.743 & 4.18 & 3 \\
\hline Businesses need to use early warning signals. & 3 & 19 & 79 & 0.828 & 4.17 & 4 \\
\hline Increased post-rescue funding. & 1 & 20 & 79 & 0.751 & 4.08 & 5 \\
\hline There needs to be early planning and preparation before commencement. & 0 & 21 & 79 & 0.685 & 4.04 & 6 \\
\hline Creditors need to play an active role in the business rescue process. & 4 & 11 & 85 & 0.717 & 4.03 & 7 \\
\hline Banks and financial institutions need to be proactively involved in the business rescue. & 4 & 17 & 69 & 0.784 & 4.01 & 8 \\
\hline Specialised courts need to be established. & 3 & 17 & 80 & 0.775 & 4 & 9 \\
\hline Employees of the company must be highly motivated. & 13 & 31 & 56 & 0.992 & 3.56 & 10 \\
\hline A key focus of the business rescue must be the company strategy. & 11 & 35 & 54 & 0.953 & 3.55 & 11 \\
\hline Government and related agencies need to be proactively involved in business rescue. & 17 & 21 & 62 & 0.983 & 3.55 & 11 \\
\hline Business rescue time frame should be increased from 6 months to a year. & 19 & 25 & 56 & 0.968 & 3.45 & 13 \\
\hline
\end{tabular}

Source: Rajaram, R., 2016, 'Success factors for business rescue in South Africa', Unpublished doctoral dissertation, University of KwaZulu-Natal, Pietermaritzburg SD, standard deviation. 
the main factor contributing to a failed business rescue). Businesses should be educated about early warning signals as a sign of financial distress to facilitate the early planning and preparation for a business rescue.

Establishing an effective business plan is also an important factor for successful business rescue as is the business rescue time frame being increased from 6 months to a year. The issue of post-rescue funding being available for a successful business rescue is again emphasised. The issue of abuse by management and business rescue practitioners was highlighted as a crucial deterrent to business rescue success. The research also indicates that business rescue practitioners must ensure that employees of the company in business rescue are highly motivated for a successful business rescue. This is related to effective communication, a quality that a business rescue practitioner must possess. The company strategy is another important factor that businesses should consider for successful business rescue. The use of liquidators as business rescue practitioners highlights the potential for misguided attempts at business rescue because of their training to dissolve rather than rehabilitate a business. Government and related agencies, as well as banks, creditors and other financial institutions also need to be involved in the business recue process. In addition, specialised courts are critical for a successful business rescue.

\section{Ranking}

Whilst the respondents' feedback in Table 3 provided an indication of success factors, these factors had to be ranked according to their mean scores to establish their importance - provided above in Table 3 . The ranking of the mean scores in Table 3 was triangulated with the responses from the seven business rescue practitioners interviewed to establish the important factors for the improvement of the success rate of business rescues in South Africa.

The interviewees felt that the accreditation of business rescue practitioners would contribute to an improved success rate and this supports the findings from the quantitative methodology. This finding also confirms feedback from the members of TMA-SA, namely that the implementation of strict accreditation criteria was the highest ranking factor that would contribute to a successful business rescue. These findings are supported by the view of researchers that a strong business rescue practitioner is vital to ensure that the rescue is a success (Bezuidenhout 2012; Levenstein 2011). International research into the Finnish Restructuring of Enterprises Act indicated that the management of the rescue is an important factor in determining whether the rescue will be successful or not (Collett, Pandit \& Saarikko 2014).

The accreditation of business rescue practitioners will address many of the complaints relating to these practitioners. The complaints are about practitioners filing for termination of business rescue too late in order to earn more fees (Du Preez 2012), poor quality of work coupled with exorbitant fees (Pretorius 2013) and their inability to control costs
(Visser 2013). These findings concur with the study by Pretorius (2015) when the role of the business rescue practitioner as a disproportionate influencer was explored. Du Preez (2012), when analysing the status of postcommencement finance in South Africa, stated that a primary reason for the lenders' reluctance to fund a business rescue lies in the profile of a business rescue practitioner.

An important component of a successful financial rehabilitation is competent leadership (Bibeault 1999:97). Balgobin and Pandit (2001:304) concurred with this finding by stressing the importance of human resources to effect a successful turnaround. They identified that effective management of all stakeholders is a priority and would greatly improve the chances of a successful turnaround. In a legislated turnaround, effective leadership can be obtained through a system of accreditation (Loubster 2010; Museta 2011; Pretorius \& Rosslyn-Smith 2014).

The responses from the interviewees indicated that earlier filing for business rescues would improve the success rate of rescues. This finding complements the findings of the quantitative methodology that businesses need to heed early warning signals to anticipate financial distress. The study ranked this factor as having the fourth highest impact on a successful rescue. In order to successfully rehabilitate a distressed company, it is important that the company's economic vulnerabilities are diagnosed and responded to as early as possible (Bussiere \& Fratzscher 2006:956). In the South African context, it is essential that the commencement of business rescue occur as early as possible to improve the chances of success (IoDSA 2009:2). Levenstein (2011:4) recommended that companies diagnose early warning signs and apply for business rescue as early as possible. The early detection of financial distress and a timeous response has been noted as a key success factor in the rehabilitation of a distressed business (Borio 2012:5). An analysis of the business rescue process highlighted the need to be proactive by engaging with all stakeholders prior to the application for business rescue (Van der Burgh 2013). This will facilitate the early application of a business rescue.

Because of the stringent deadlines and time frames that are imposed by business rescue legislation, the CIPC suggested that as much of the financial analysis of a distressed company as possible should take place prior to the application for business rescue (Terblanche 2014). The benefits of early application for business rescue were highlighted in the successful rescue of Shelly Point Hotel (Muller 2014). Because of the owner's proactive stance in detecting financial difficulties relating to cash flow and working capital, an early application for business rescue was filed. This resulted in more time being available to arrange for post-rescue funding and to reduce costs.

Whilst there is a convergence in the findings between the mixed-methodology approach of this study and existing literature, the interviews established an effective method of facilitating the early application. It was recommended that 
the requirements of s. 129(7) of the business rescue legislation be viewed in a more serious manner. This section compels management of a distressed company to provide reasons to all affected parties as to why management did not apply for the commencement of business rescue. The enforcement of this responsibility will ensure that financially distressed businesses apply for business rescue earlier.

Another factor the interviewees recommended to improve the success rate of business rescues is an increase in postrescue funding. The literature noted that a key success of the Chapter 11 process is the availability of rescue funding (Mindlin 2013). This view is supported by Bharath et al. (2013:13), who correlated the increased success rate of Chapter 11 with the increase in funding available. The results of the quantitative methodology ranked the availability of post-rescue funding as having the fifth highest impact on a successful business rescue.

The interviews identified innovative ways to increase the availability of post-rescue funding. Because of the concern of banks relating to the competency of the business rescue practitioner and management, an interviewee suggested the establishment of a closer relationship with funders. The close relationship will enable a funder to be involved in and monitor the business rescue. It would allow for additional oversight, management of the rescue and provide a level of comfort to the funder that their funds are properly invested. In this relationship, concerns that funders have about management can be effectively addressed by either replacing management or complementing their skills. The interviewees also highlighted the potential for the formation of private funding for business rescues in South Africa. Based on the international experience of an interviewee, there are many private funders in the US Chapter 11 turnaround sector. He believes that there are similar opportunities in South Africa to increase the post-rescue commencement funding.

The interviewees indicated that the establishment of specialised business rescue courts would increase the chances of a successful business rescue. This response is similar to the ninth highest success factor established by the findings of the quantitative methodology. It addresses the concerns raised regarding the ability of the South African judiciary to handle business rescue cases. The concerns relate to the lack of specialist business rescue judges, contradictory judgements and judges that do not understand business rescue legislation (Ensor 2014). Pretorius (as cited in Visser 2013) noted that there have been several contradictory business rescue judgements. This highlights the need for courts that have the necessary business rescue skills. According to Mindlin (2013:18), an important feature that contributes to the success of Chapter 11 rescues in the USA is the presence of experienced judges who have specialist knowledge. The interviewees stated that until this is achieved, there should be more appeals against the Supreme Court of Appeal.

Although not established as a success factor by the results of the quantitative methodology, the interviewees felt that an increased awareness of business rescue legislation would improve the success rate. This could be undertaken by an educational campaign to improve the business community's awareness and understanding of business rescue legislation. According to the business rescue practitioners interviewed, there is a stigma attached to companies that file for business rescue. Business rescue should not be confused with liquidation, nor should it be perceived to be a death sentence. Creating an awareness of business rescue legislation would improve the success rate as companies would be able to file earlier.

The interviews also identified greater flexibility from labour on their demands that jobs be saved during business rescue. A primary objective of business rescue is the preservation of jobs (Rushworth 2010). However, an effective turnaround strategy often involves aggressive retrenchment to prevent further decline in the financial fortunes of a distressed business (Pearce \& Robbins 2008:129). In order to achieve a successful rescue, there must be a compromise between retrenchments and job preservation. The interviewees mentioned that there is an unnatural wish by role players, like government organisations, to protect jobs at all costs. These parties do not support a business rescue unless all jobs are saved. However, because of the expenditure required to save jobs, the company is ultimately liquidated. A greater degree of flexibility from organised labour and government would increase the success rate.

\section{Recommendations arising from the study}

In order for business rescue legislation to survive and have a meaningful impact on the South African economy, the following recommendations are made.

\section{Department of Trade and Industry and the Companies and Intellectual Property Commission}

An independent regulator should be established by the Department of Trade and Industry and the CIPC to manage the business rescue sector. The role of the Department of Trade and Industry and the CIPC should be limited to facilitating the creation of a regulator. The management and functioning of the regulator should be independent of the CIPC.

The following core responsibilities of the regulator are essential:

- Create an awareness of business rescue legislation: Educational campaigns should be established to improve the business community's understanding of the potential benefits of business rescue legislation. Business workshops and seminars should be utilised to better inform business owners and management of the technicalities relating to the legislation. The improved understanding would contribute to an increased and more effective utilisation of business rescue legislation to rehabilitate financially distressed businesses. It would also result in an earlier application for companies intending to file for business rescue. 
- Establish a framework for the accreditation of business rescue practitioners: The framework should include the skills and qualifications required for successful accreditation.

- Create a continuous development programme of training for business rescue practitioners: This will ensure that practitioners remain updated on changes to legislation and industry trends.

\section{The Justice Ministry}

The Justice Ministry should establish specialised courts to handle and fast track business rescue cases. In the interim, courts should utilise assessors with expertise in business rescue legislation and commercial law.

\section{The financial sector}

The financial sector needs to adopt a more proactive stance on the provision of business rescue finance. The proactive stance relates to the financial sector's involvement in commencing business rescue and the provision of postrescue funding.

Based on financial records maintained by banks, businesses could have a low risk or high risk status indicator. Risk indicators that are connected to cash flows, profitability and debt ratios can be used as an early warning system to indicate the need to file for business rescue.

The study indicated that there is potential for the expansion and growth of the funding for business rescues, similar to the funding industry in the USA. The growth can be achieved by the establishment of specialist funding vehicles for companies that are in or about to file for business rescue. Management of these funds would require an in-depth knowledge of business rescue legislation, such as tight deadlines. It is essential to consider the funder playing a more active role in the business rescue.

The current post-rescue funding environment requires an improved working relationship between funders, management and business rescue practitioners. A closer working relationship will facilitate an effective mechanism for the business rescue practitioners to address concerns relating to the management of the business rescue.

\section{Management}

In addition to efforts by the regulator to improve the awareness of business rescue legislation, management should ensure that they understand and comply with business rescue legislation. Business rescue legislation should only be utilised for the intended purpose of rehabilitating a financially distressed firm. Any abuse of the legislation should be avoided. Strict penalties should be imposed on those found guilty of abusing the process.

In order to ensure that financial distress is detected timeously, consideration should be given to the use of early warning distress signals. The early detection of financial distress will facilitate an earlier application for business rescue. In the event that management decides to apply for business rescue, an effort must be made to communicate details of the filing to all affected parties. Because of tight deadlines, important decisions and planning must be undertaken prior to the application for the business rescue. Examples of these decisions are the appointment of a business rescue practitioner and the negotiation of postcommencement finance. In the event that management of a financially distressed company does not apply for business rescue, the requirements of s. 129(7) must be complied with immediately.

\section{Conclusion}

This study found that poorly skilled business rescue practitioners are very often the cause of failed rescues. The negative impact is mainly attributable to a lack of skills and knowledge of the business rescue practitioner. This study also highlighted the negative impact of appointing a liquidator as a business rescue practitioner because of the different skill set possessed by a liquidator, compared to a successful business rescue practitioner. Furthermore, this study found that business rescue practitioners are responsible for failed business rescues because of their complicit role in abusing legislation. This abuse was also found in management's decision either to file for business rescue in order to delay liquidation or to resist filing because of their failure to detect financial distress. This study also found that management's poor awareness of rescue legislation and/or lateness in applying for relief contributed to the failure of business rescue.

The low success rate of business rescue can be improved by adopting and implementing the recommendations of this study. An increased success rate could be achieved by the establishment of an independent regulator to manage the business rescue sector. The implementation of an accreditation framework by the regulator would enhance the impact of business rescue legislation. This would facilitate a more vibrant business rescue sector and an improved success rate, ultimately ensuring the survival of business rescue in South Africa. Using a triangulation approach, this study has confirmed existing literature and has contributed new knowledge to understanding business rescue in South Africa.

\section{Acknowledgements Competing interests}

The authors declare that they have no financial or personal relationships that may have inappropriately influenced them in writing this article.

\section{Authors' contribution}

All authors equally contributed to the writing of this article. 


\section{References}

Baird, S., 2014, 'An empirical investigation of successful, high performing turnaround professionals: Application of the dynamic capabilities theory', Unpublished Ph.D. dissertation, Georgia State University, Atlanta, GA.

Balgobin, R. \& Pandit, N., 2001, 'Stages in the turnaround process: The case of IBM UK', European Management Journal 19(3), 301-316. https://doi.org/10.1016/ S0263-2373(01)00027-5

Bezuidenhout, P., 2012, 'A review of business rescue in South Africa since implementation of the Companies Act (71/2008)', Unpublished M.B.A.-thesis, North-West University, Potchefstroom.

Bharath, T., Panchaegesan, V. \& Werner, I., 2013, The changing nature of Chapter 11, Working paper no. 461, Indian Institute of Management, Bangalore.

Bibeault, D., 1999, Corporate turnaround, how managers turn losers into winners, Beard Books, Washington, DC

Borio, C., 2012, The financial cycle and macroeconomics: What have we learnt? viewed 05 February 2016, from http://www.bis.org/publ/work395.pdf

Bracewell \& Giuliani., 2012, Chapter 11 of the United States Bankruptcy Code Background and summary, viewed 04 March 2016, from https://www.insol.org/ files/Fellowship\%202015/Session\%203/Chapter_11_Overview.pdf

Bradstreet, R.S., 2014, 'Averting liquidations with business rescue: Does a section 155 compromise place the bar too high?', Stellenbosch Law Review 25(3), 549-565.

Burke-le Roux, A. \& Pretorius, M., 2017, 'Exploring entrepreneurial learning during formal business rescue processes: Insights from the South African experience', $S A$ Journal of Human Resource Management 15(1), 1-15. https://doi.org/10.4102/ sajhrm.v15i0.733

Bussiere, M. \& Fratzscher, M., 2006, 'Towards a new early warning system of financial crises', Journal of International Money and Finance 25(6), 953-973. https://doi. org/10.1016/j.jimonfin.2006.07.007

Calitz, J. \& Freebody, G., 2016, 'Is post commencement finance proving to be the thorn in the side of business rescue proceedings under the 2008 Companies Act?', thorn in the side of busines
De Jure 49(2), 265-287.

Coakes, S. \& Steed, L., 2010, SPSS: Analysis without Anguish, 17th edn., Kyodo Publishing, Singapore.

Collett, N., Pandit, N. \& Saarikko, J., 2014, 'Success and failure in turnaround attempts. An analysis of SMEs within the Finnish Restructuring of Enterprises Act', Entrepreneurship \& Regional Development: An International Journal 26(1) 123-141. https://doi.org/10.1080/08985626.2013.870236

Conradie, S. \& Lamprecht, C., 2015, 'Business rescue: How can its success be evaluated at company level?', Southern African Business Review 19(3), 1-29.

Conradie, S. \& Lamprecht, C., 2018, 'What are the indicators of a successful business rescue in South Africa? Ask the business rescue practitioners', South African Journal of Economic and Management Sciences 21(1), 1-12. https://doi. org/10.4102/sajems.v21i1.1726

Correia, C., Flynn, D., Uliana, E. \& Wormald, M., 2011, Financial management, 7th edn., Juta \& Co., Cape Town.

Curado, C., 2006, The knowledge based view of the firm: From theoretical origins to future implications, Working paper no. 1/2006, Universidade Tecnica de Lisboa, Department of Management, Lisbon.

Du Preez, W., 2012, 'The status of post commencement finance for Business Rescue in South Africa', Unpublished M.B.A.-thesis, University of Pretoria, Pretoria.

Ensor, L., 2014, 'Business rescue under scrutiny as remedies fail to save stricken firms', Business Day Live, 06 August, n.p.

Fleming, G., Heaney, R. \& McCosker, R., 2005, 'Agency costs and ownership structure in Australia', Pacific-Basin Finance Journal 13(1), 29-52. https://doi.org/10.1016/j. pacfin.2004.04.001

Government Gazette, 2009, Companies Act, No 71 of 2008, Cape Town, viewed 24 May 2018, from http://www.acts.co.za/companies-act-2008

Institute of Directors in Southern Africa (IoDSA), 2009, Practice Notes: Guidance on Business Rescue, Institute of Directors in Southern Africa, Pretoria.

Jensen, M. \& Meckling, W., 1976, 'Theory of the firm: Managerial behaviour, agency costs and ownership structure', Journal of Financial Economics 3(4), 305-360. https://doi.org/10.1016/0304-405X(76)90026-X

Jones Day, 2007, Comparison of Chapter 11 of the United States Bankruptcy Code with The system of administration in the United Kingdom, the rescue procedure in France, Insolvency proceedings in Germany and The extraordinary administration for large insolvent companies in Italy, viewed 28 February 2016, from http:// www.jonesday.com/files/Publication/1ec093d4-66fb-42a6-8115-be0694c59443/ Presentation/PublicationAttachment/e5b46572-7aeb-4c34-ab2e-bee2f8f3d3c2/ Comparison $\% 20$ of $\% 20$ Chapter $\% 2011 \% 20$ (A4).pdf

Joubert, T., 2013, 'Reasonable possibility versus "Reasonable Prospect": Did business rescue succeed in creating a better test than Judicial Management?', Journal of Contemporary Roman-Dutch Law 76, 550-563.
Kastrinou, A. \& Jacobs, L., 2017, 'An 15 overview of the pre-insolvency procedures in the United Kingdom and South Africa', Turnaround Management and Bankruptcy: A Research Companion 69, 290-305.

Levenstein, E., 2011, Business rescue: Problems and pitfalls, corporate governance conference, Werkmans Attorneys, Johannesburg.

Lotheringen, A., 2013, Going out of business rescue or getting rescued. What are the odds?, viewed 04 December 2015, from http://www.tma-sa.com/events/eventpresentations/60-presentation-by-amanda-lotheringen-of-cipc-october-2013/ file.html

Loubser, A., 2010, 'Some comparative aspects of corporate rescue in South African company law', Unpublished Ph.D.-thesis, University of South Africa, Johannesburg.

McKinley, W., Latham, S. \& Braun, M., 2014, 'Organisational decline and innovation: Turnarounds and downward spirals', Academy of Management Review 39(1), 89-110. https://doi.org/10.5465/amr.2011.0356

Mindlin, P., 2013, Comparative analysis of chapter six of the South African Companies Act, No. 71 of 2008, viewed 04 May 2016, from https://www.thedti.gov.za/ business_regulation/presentations/symposium1of6.pdf

Mkhondo, S. \& Pretorius, M., 2017, 'Funding structures in business reorganisations: Locating the role of pre-packaging as a restructuring tool', Journal of Contemporary Management 14(1), 831-863.

Muller, J., 2014, Business rescue can work, viewed 05 January 2016, from http://www. financialmail.co.za/features/2014/03/27/business-rescue-can-work

Museta, M., 2011, 'The development of business rescue in South African Law', Unpublished L.L.M.-thesis, University of Pretoria, Pretoria.

Pearce, J. \& Robbins, D., 2008, 'Strategic transformation as the essential last step in the process of turnaround', Business Horizons 51(2), 121-130. https://doi. org/10.1016/j.bushor.2007.11.003

Pretorius, M., 2013, 'New business heroes?', Fin24, 03 March, n.p.

Pretorius, M., 2015, Business rescue status quo report: Final report, Business Enterprises at University of Pretoria, Pretoria.

Pretorius, M., 2016, 'The debtor-friendly fallacy in business rescue: Agency theory moderation and quasi relationships', South African Journal of Economic and Management Sciences 19(4), 479-496. https://doi.org/10.4102/sajems. v19i4.1385

Pretorius, M. \& Rosslyn-Smith, W., 2014, 'Expectations of a business rescue plan International directives for Chapter 6 implementation', Southern African Busines Review 18(2), 108-139.

Priem, R. \& Butler, J., 2001, 'Is the resource-based view a useful perspective for strategic management research?', The Academy of Management Review 26(1), 22-40.

Rajaram, R., 2016, 'Success factors for business rescue in South Africa', Unpublished doctoral dissertation, University of KwaZulu-Natal, Pietermaritzburg.

Rajaram, R. \& Singh, A.M., 2018, 'Competencies for the effective management of legislated business rehabilitations', South African Journal of Economic and Management Sciences 21(1), 1-9. https://doi.org/10.4102/sajems.v21i1.1978

Rushworth, J., 2010, 'A critical analysis of the business rescue regime in the Companies Act 71 of 2008', Acta Juridica 2010(1), 375-408.

Saunders, M., Lewis, P. \& Thornhill, A., 2003, Research methods for business students, 3rd edn., Pearson Education, Essex.

Sekaran, U. \& Bougie, R., 2013, Research methods for business: A skill building approach, 6th edn., John Wiley and Sons, Chichester.

Spulber, D., 2009, The theory of the firm: Microeconomics with Endogenous Entrepreneurs, Firms, Markets and Organisations, Cambridge University Press, New York.

Terblanche, D., 2014, With 8\% Success rate, something serious amiss with 'business rescue', viewed 17 January 2016, from http://www.biznews.com/thoughtleaders/2014/02/06/success-rate-just-8-something-serious-amiss-businessleaders/2

Trahms, C., Ndofor, H. \& Sirmon, D., 2013, 'Organisational decline and turnaround: A review and agenda for future research', Journal of Management 39(5), 1277-1307. https://doi.org/10.1177/0149206312471390

Van der Burgh, A., 2013, 'Business rescue and compromise: Two years later, a remedy or a quandary?', Paper presented at a Business Rescue workshop, Pretoria.

Visser, A., 2013, 'Business rescue rate has some way to go', Business Day Live 27 March, n.p.

Voller, R., 2015, Administration of business rescue: CIPC Perspective, Companies and Intellectual Property Commission, Pretoria.

Warren, E. \& Westbrook, J., 2009, 'The success of Chapter 11: A challenge to the critics', Michigan Law Review 107(4), 603-641.

Wernerfelt, B., 1984, 'A resource-based view of the firm', Strategic Management Journal 5, 171-180. https://doi.org/10.1002/smj.4250050207

Whetton, D., 1980, 'Organisational decline: A neglected topic in organisational science', Academy of Management Review 5(4), 577-588. 